\section{P-217尿路上皮におけるラミニンの発現パターン 解析}

\section{筑波大学 臨床医学系1) \\ 大阪大学 蛋白質研究所 ${ }^{2 !}$}

服部一紀1) 河合弘-1) 関戸哲利1）馬渕麗子1）高岡栄一 郎 ${ }^{1)}$ 赤座英之 ${ }^{1)}$ 関口清俊2)

【目的】ラミニンは基底膜の構成成分の中でも、インテグリンを 介して直接細胞と接しており、細胞の分化や增殖を調節している

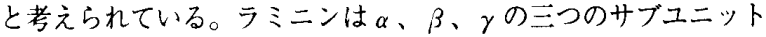
鎖より構成され、それらの組み合わせにより、これまでに少なく とも12種類のラミニンが同定されている。各ラミニンにより、機 能や役割が異なると考えられている。尿路組織に打けるラミニン バリアントの発現について検討したので報告する。【対象と方法】 初代培養した正常七卜尿路上皮細胞及び線維来細胞よりRNAを抽 出し、RT-PCR法にて备ラミニンバリアントの発現を調べた。ま た、蛋白を抽出し、Western blotにて蛋白レベルでの発現も検討し た。結果】尿路上皮細胞が発現寸る $\alpha$ 鎖は、主に $\alpha 3 \mathrm{a} 、 \alpha 5$ であ り、一方線維芽細胞が発現する $\alpha$ 鎖は $\alpha 2 、 \alpha 4$ 主であった。 $\beta$

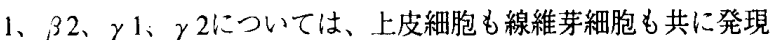
していた。【結論】尿路組織における各ラミニンバリアントの発 現は、従来より報告されている他雨器の上皮細胞や線維芽細胞の 発現パターンとほほ同様であった。今後、これら主要なラミニン バリアントの尿路組織に㧍ける機能や役割の解析が必要である。

尿路上皮 基底膜 ラミニン

\section{P-219 泌尿器科開放手術における術後早期感染症 と抗菌化学療法の検討}

\section{産業医科大学 泌尿器科1)}

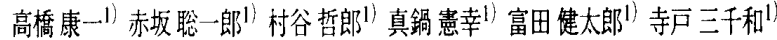

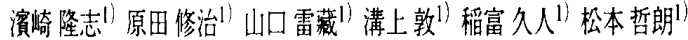

【目的】泌尿器科開放手術に伴う合併症のう方術後早期感染症 と抗菌化学療法の現況を検討した。【対象と方法】1996年1月から 1999年11月までに開放手術が施行された入院患者274例（男性227 例：女性47例、平均年齢 $50.2 \pm 23.8$ 歳) に対し、術後早期感染症 （1ヶ月以内）に関し、抗菌化学療法を含めた臨床的検討を行っ た。【結果】術後早期感染症は52例（18.9\%）に70件みられた。無 菌、準無菌手術で頻度は低く $(3.2 \% 、 16.9 \%)$ 污染、感染手術で は非常に高かった $(63.2 \% 、 50.0 \%)$ 。主な起炎菌は、グラム陽性 球菌31株、グラム陰性桿菌15株（MRSA17株、E. faecalis8株、 P.aeruginosa 5株）であった。術後予防的投与にはペニシリン系、 第1、2世代七フェム系菜が主に使用された。感染症発症時の empiric therapyには第 4 世代七フェム、カルバペ辛ム系薬が多く選 択され、起炎菌同定後はペニシリン系またはMRSA治療抗菌莧の 類度が高くなった。まとめ】泌尿器科開放手術の術後早期感染 症の起炎菌ではMRSAや腸球菌などグラム陽性球菌が重要であり、 術後予防的、または感染症発症時のempiric therapyに扩引るてエ 么系抗菌薬の使用には注意が要する。

\section{開放手術 術後感染症 抗菌化学療法}

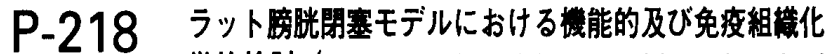
学的㛟期 (Functional and Immunohistochemical Analysis on Rat Obstructed Bladder)

\section{筑波大学 医学研究科1) \\ 筑波大学臨床医学系 2 )}

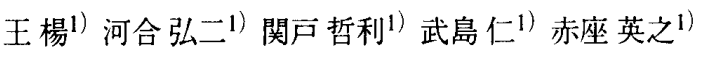

[目的]下部尿路閉塞に伴う膀胱組織の修復の過程について検討す ることを目的として、強度の閉塞を伴うラット膀肤閉塞モデルを 作成し、組織学的な変化拉よび機能的な解析を行うと共に免疫組 織化学的検討を行った。[対象と方法] SDラット麻酔下にカテーテ ル（内径 $0.6 \mathrm{~mm} ）$ を膀胱内に挿入、尿道を結禁した。術後3、5、7、 28日目に膀胱を摘出し、固定包埋を行った。また膀羘閉塞群では 5、7及び28日後に膀脱内圧測定を行うとともに、平滑筋紐胞の分 化マーカーであるSM-alpha actin、tropomyosin 及びvinculinの発現を 免疫組織化学的に検討した。[結果]組織学的には閉塞群では膀胱 重量の増加、膀脱壁の肥厚、上皮細胞の增殖などの変化が認めら れた。また、28日後に俆膜層の肥厚と槳膜内に损けるspindle-shape 細胞の出現が観察できた。膀胱内圧の測定では膀胱容量の増加が 認められない群(type I) と著明に膀胱容量が增加した群(type II)に大 別された。免疫染色でSM-alpha actinには有意な変化を認めなかっ たがtropomyosinの一過性の增加が観察された。 type I群の膀胱では 有意にvinculinの発現が高かった。[結論]下部尿路に伴う平滑筋層 の修復が膀胱機能、特に蓄尿機能と関連することが示唆された。 尿道結禁 尿力学 侮很

\section{P-220 泌尿器科医の立埸からのFoley catheterの 基礉的検即}

\begin{abstract}
㙵厚生病院
米沢市立病院 ${ }^{2)}$

伊東学1) 高岩 正至 ${ }^{2)}$ 吉田 純也 2

【目的】 Foley catheter（カテ）の基礎的検討をおこない，カテに関 するトラブルのリスクを低減させる．【方法】身近に使用してい る数種類のカテについて, A.力テ表面の特に凹凸の有無と程度, B.内腔の広さ，について検討した．A.はカテの切片を 2 枚のプレ パラートで軽く圧迫固定し，太陽の間接光線下に透過型影微鏡で 観察した. B.は12〜20Frのカテを幅約 $1 \mathrm{~mm}$ の輪状に切断し，接写 写真を拡大して内腔断面積を計算した【【結果】A.シリコン製に比 し，プラスチックまたはラテックス製は表面の凹凸が大であった． B.シリコン製に比し，プラスチックまたはラテックス製の内腔は 小であった. またシリコン製品間にも内腔断面積に約 $25 \%$ 差を 認めた。考案】検査や手術後の尿道の違和感や狭窄などのトラ ブルはカテの外径が太いほど尿道粘膜への負担が大となり起こり やすく，血尿や膿尿患者のカテがよく詰まるなどのトラブルはカ テの内腔が小で，また使用期間が長いほど起こりやすい．血尿や 膿尿の程度と予測使用期間から内腔断面積の至適値を決定し，そ の値をクリアーする最小外径のカテを選択すべきことを，各科医 師や看護士にも周知徹底すべきであると考える. 当日は，各種力 テの基礎的検討結果について，経済的視点をも含めた考察を加之 報告したい.
\end{abstract}

Foley catheter 表面の凹凸 内腔の広さ 